\title{
Electrochemical characterization and determination of carbamazepine as pharmaceutical standard and tablet content on gold electrode
}

\author{
Nemanja P. Trišović ${ }^{1}$, Bojan Đ. Božić ${ }^{1}$, Slobodan D. Petrović ${ }^{1}$, Svetlana J. Tadić ${ }^{2}$, Milka L. Avramov Ivić $^{3}$ \\ ${ }^{1}$ University of Belgrade, Faculty of Technology and Metallurgy, Karnegijeva 4, 11120 Belgrade, Serbia \\ ${ }^{2}$ Galenika a.d., Batajnički drum bb, 11080 Belgrade, Serbia \\ ${ }^{3}$ University of Belgrade, ICTM, Institute of Electrochemistry, Njegoševa 12, 11000 Belgrade, Serbia
}

\begin{abstract}
The anodic behaviour of carbamazepine (CBZ), an anticonvulsant drug, has been studied on gold electrode in $0.1 \mathrm{~mol} \mathrm{dm^{-3 }}$ phosphate buffer of $\mathrm{pH} 7.0$ by using cyclic voltammetry. It has been found that the value of the oxidative current of pure CBZ at $0.90 \mathrm{~V} v \mathrm{vs}$. SCE is a linear function of the concentration in a range from $1.0 \times 10^{-7}$ to $1.0 \times 10^{-4} \mathrm{~mol} \mathrm{dm}^{-3}$. The detection of CBZ in the concentration of $1.0 \times 10^{-8} \mathrm{~mol} \mathrm{dm}^{-3}$ is among the lowest that have been reported for this drug using voltammetric techniques. CBZ as a content of tablet Galepsine ${ }^{\circledR}$ has been quantitatively determined. It has also been demonstrated that the modification of gold electrode with bovine serum albumin (BSA) results in a decrease of the oxidative peak current due to the binding of the drug to BSA.
\end{abstract}

SCIENTIFIC PAPER

UDC 543.552:615.03:615.2

Hem. Ind. 68 (2) 207-212 (2014)

doi: 10.2298/HEMIND130125045T

Keywords: carbamazepine, voltammetric determination, gold electrode.

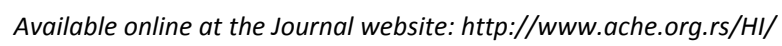

Carbamazepine (CBZ) is one of the safest and the most effective anticonvulsant drugs, which is used in the management of tonic-clonic, complex partial and mixed-type seizures for a long time [1,2] (Fig. 1). Currently, various mechanisms of its action are proposed. The anticonvulsant activity of CBZ principally involves limitation of seizure propagation by reduction of posttetanic potentiation of synaptic transmission [3]. The drug has also demonstrated sedative, anticholinergic, antidepressant, muscle relaxant, antiarrhythmic, antidiuretic and neuromuscular transmission inhibitory actions [4].

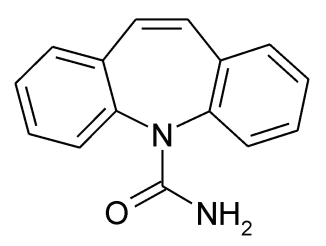

Figure 1. Chemical structure of carbamazepine (5H-dibenzo[b,f]azepine-5-carboxamide).

Several analytical methods have been presented in the literature for the determination of $C B Z$ and its impurities in the bulk drug and biological fluids. Fluorescence polarization immunoassay [5] and HPLC [6-8] are usually used for the routine determination of this and other anticonvulsant drugs. Conventional chromatographic techniques, such as gas chromatography

Correspondence: Nemanja P. Trišović, University of Belgrade, Faculty of Technology and Metallurgy, Karnegijeva 4, 11120 Belgrade, Serbia.

E-mail: ntrisovic@tmf.bg.ac.rs

Paper received: 25 January, 2013

Paper accepted: 6 June, 2013
$[9,10]$, gas chromatography combined with mass spectrometry [11] and micellar electrokinetic capillary chromatography [12] have also been employed. Few recent studies have investigated the applicability of electrochemical methods for the characterization of CBZ. Its electrochemical oxidation at glassy carbon electrode (GCE) in phosphate buffer solution ( $\mathrm{pH}$ 7.4) has been studied by Kalanur and Seetharamappa [13]. Two oxidation peaks have been observed, whereby no peak has been observed in the reverse scan suggesting that the oxidation process is an irreversible one. The probable reaction mechanism of oxidation of CBZ has been proposed based on the reported mechanism of oxidation of imipramine (3-(10,11-dihydro-5H-dibenzo[b,f]azepin-5-yl)- $N, N$-dimethylpropan-1-amine), which has an almost similar structure and belongs to same class of tricyclic compounds. Taking into account that the voltammogram of imipramine closely resembled that of CBZ, the authors have proposed that the reaction mechanism includes the oxidation of $\mathrm{CBZ}$ to a radical, which dimerizes rapidly and subsequently undergoes oxidation to form a dimmer radical. Veiga et al. have applied a multiwalled carbon nanotubes film-coated GCE for the voltammetric determination of CBZ in phosphate buffer solution (pH 6.89) [14]. The electrochemical reduction of $C B Z$ in acetonitrile and dimethylformamide using GCE and microelectrode has also been studied [15]. The reduction process is suggested to follow electrochemical-chemical mechanism involving a two electron transfer accompanied by a first order reaction. Pruneanu et al. have employed graphene-gold nanoparticle composite deposited on gold electrode to detect CBZ [16]. A two-wave oxidation peak has been observed accompanied by a small reduction 
peak, which have suggested an oxidation pathway with formation of dimmers similar to the one proposed in [13]. Lin et al. have used differential pulse voltametry to determine the serum level of $C B Z$ in rabbits and reported a detection limit of $59.2 \times 10^{-8} \mathrm{~mol} \mathrm{dm}^{-3}$ [17]. Excellent enhancement effects on electrochemical response of CBZ have been achieved through the use of fullerene- $\mathrm{C}_{60}$ modified GCE [18]. Cyclic voltammogram has shown two oxidation and reduction peaks at fullerene- $\mathrm{C}_{60}$ modified GCE in phosphate buffer solution $(\mathrm{pH} 7.2)$. In this case, a detection limit of $16.2 \times 10^{-9} \mathrm{~mol}$ $\mathrm{dm}^{-3}$ has been reported.

Different electrode materials have offered possibilities for improving the electrochemical behavior of $\mathrm{CBZ}$, as well as for reaching lower limits of its detection. The aim of this paper is at first the investigation of the electrochemical behaviour of CBZ (pharmaceutical standard) on gold electrode and gold electrode modified with BSA using cyclic voltammetry. The electrochemical identification of its tablet content is presented in this regard. The proposed method is observed to be very sensitive and allows determination of $C B Z$ in a wide concentration range in solid dosage forms.

\section{EXPERIMENTAL}

\section{Materials}

The CBZ standard (Sigma Aldrich) was used as a pure substance without further purification, dissolved (1 vol.\% of methanol and 99 vol.\% of phosphate buffer) and added into the electrolyte $\left(0.1 \mathrm{~mol} \mathrm{dm}^{-3}\right.$ phosphate buffer, $\mathrm{pH} 7.0$ ), so that the final range of the drug concentrations was $1.0 \times 10^{-8}-1.0 \times 10^{-4} \mathrm{~mol} \mathrm{dm}^{-3}$.

The commercial CBZ, as a content of Galepsin ${ }^{\circledR}$ tablets (Galenika a.d., Serbia), was dissolved in methanol and added into the electrolyte $\left(0.1 \mathrm{~mol} \mathrm{dm}^{-3}\right.$ phosphate buffer, $\mathrm{pH}$ 7.0); the final range of concentrations was $1.0 \times 10^{-6}-1.0 \times 10^{-4} \mathrm{~mol} \mathrm{dm}^{-3}$. BSA (Sigma Aldrich) was used as a pure substance without further purification and modification. Phosphate buffer solution was prepared by standard procedure and $\mathrm{pH}$ has been measured by Mettler Toledo (FiveGo) pH Meter. Monobasic sodium phosphate and dibasic sodium phosphate were p.a. purity. Water was purified by Milli-Q system.

\section{Apparatus and preparation of electrode surfaces}

Standard equipment was used for the cyclic voltammetry measurements and the three electrode electrochemical cell was described in detail previously [19-21]. Polycrystalline gold (bare gold) served as the working electrode; a gold wire was used as the counter electrode and a saturated calomel electrode as the reference electrode. All the potentials are given vs. SCE. Prior to the addition of CBZ, the electrolyte was deoxy- genated by purging with nitrogen. All the experiments were performed at room temperature.

BSA modified gold electrode was prepared by transferring a droplet of $2 \times 10^{-6} \mathrm{~cm}^{3}$ of BSA solution onto the surface of gold electrode and by air-drying overnight. The electrode was then soaked in sterile water for at least $4 \mathrm{~h}$ before being rinsed with water to remove any unadsorbed BSA [22].

Polycrystalline gold (surface area $0.500 \mathrm{~cm}^{2}$ ), which served as the working electrode, was polished with diamond paste, cleaned with a mixture of $18 \mathrm{M} \Omega \mathrm{cm}$ deionised water and sulfuric acid and further cleaned with $18 \mathrm{M} \Omega \mathrm{cm}$ deionised water in an ultrasonic bath.

\section{RESULTS AND DISCUSSION}

Due to its low water solubility $\left(-72 \times 10^{-5} \mathrm{~mol} \mathrm{dm}^{-3}\right.$ at $25^{\circ} \mathrm{C}$ ), the electrochemical characterization of CBZ has been mostly performed with addition of organic solvents such as acetonitrile and dimethylformamide [14-17]. However, these solvents interact with the surface of gold electrode and easily adsorb on it [23], which makes them inconvenient for the purposes of the present research. In the initial experiment, we have employed bicarbonate solution as electrolyte, but the obtained cyclic voltammogram of CBZ has shown its low electrooxidation activity when compared with the ones obtained in phosphate buffer solution. Because of this, phosphate buffer has been further used for the electrochemical determination of CBZ. To overcome the problem of the low solubility of CBZ and excipients used in tablet (Galepsin ${ }^{\circledR}$ ), methanol has been added to the electrolyte $(0.1$ and 1 vol.\% for the determination of CBZ as pharmaceutical standard and tablet content, respectively). It has already been shown that methanol is not electroactive on gold electrode at the value of the applied sweep rate $\left(50 \mathrm{mV} \mathrm{s}^{-1}\right)$ [24].

In the presence of the CBZ standard (at the concentration of $1.0 \times 10^{-8} \mathrm{~mol} \mathrm{dm}^{-3}$ ), the reaction of the oxidation occurs in the area of the oxide formation with the apparent anodic activity from 0.90 to $1.10 \mathrm{~V}$, as it is presented in Fig. 2. The small lowering of the first gold oxide peak at $0.75 \mathrm{~V}$ is also apparent only for the concentration of $1.0 \times 10^{-8} \mathrm{~mol} \mathrm{dm}^{-3}$. In the reverse sweep, the reaction of the oxide reduction has been decreased in the presence of $C B Z$ at $0.44 \mathrm{~V}$, which may be attributed to the reduction of products formed in the described anodic reactions, as it is the case with macrolide antibiotics [19-21]. Furthermore, for the all of the investigated concentrations of $\mathrm{CBZ}$ from $1.0 \times 10^{-7}$ to $1.0 \times 10^{-4} \mathrm{~mol} \mathrm{dm}^{-3}$, in anodic direction, cyclic voltammograms exhibited the changed shape compared to the cyclic voltammograms in the presence of $1.0 \times 10^{-8}$ mol $\mathrm{dm}^{-3}$ of $C B Z$, as well as in its absence. The increasing anodic current values from 0.30 to $1.10 \mathrm{~V}$ due to the increased CBZ concentrations lead to the 


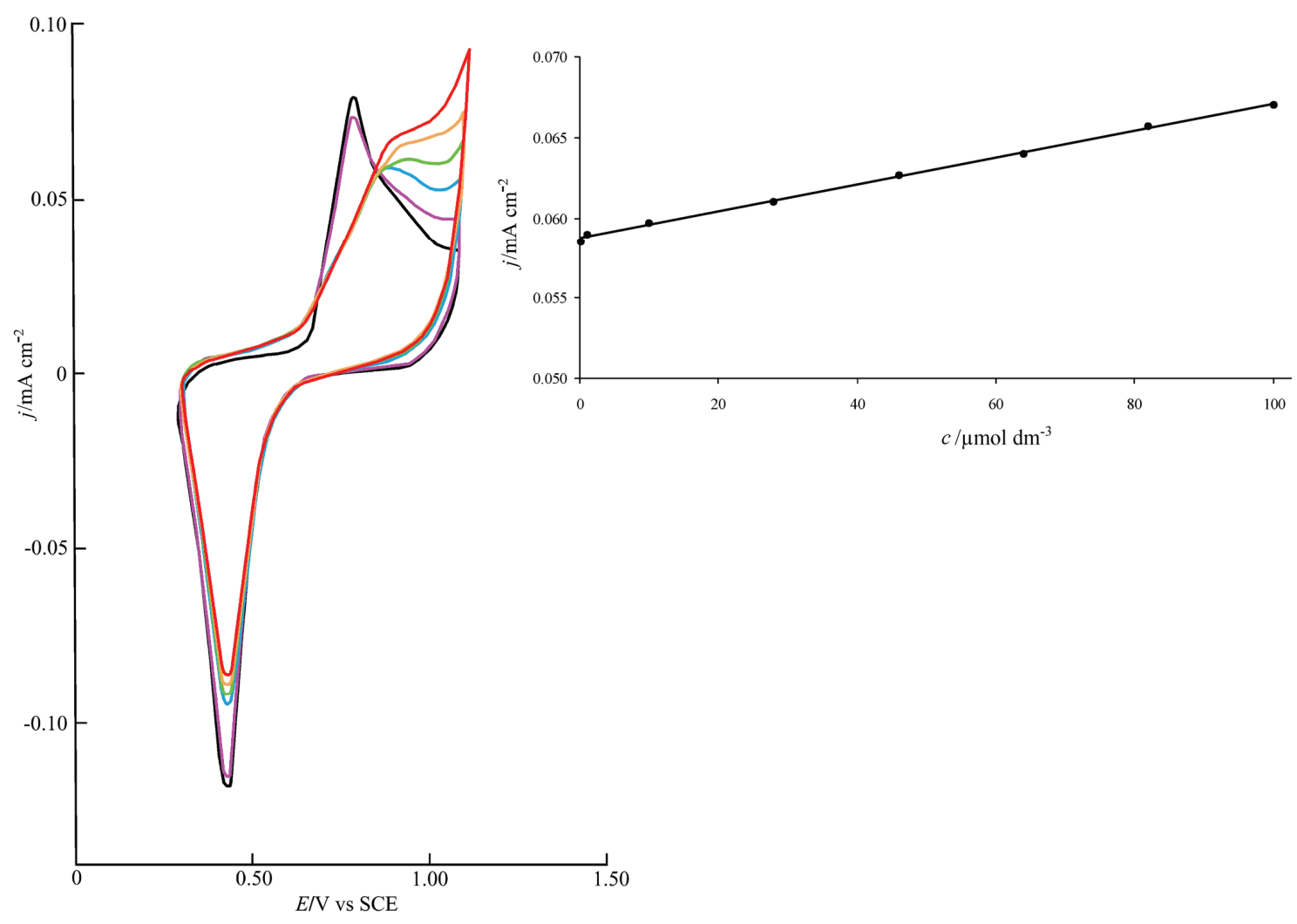

Figure 2. The cyclic voltammograms of bare gold electrode (black line) and in the presence of the carbamazepine (CBZ) standard in the concentration from $1.0 \times 10^{-8}$ to $1.0 \times 10^{-4} \mathrm{~mol} \mathrm{dm}^{-3}\left(1.0 \times 10^{-8} \mathrm{~mol} \mathrm{dm}^{-3}\right.$ pink line, $1.0 \times 10^{-7} \mathrm{~mol} \mathrm{dm}^{-3}$ blue line, $1.0 \times 10^{-6} \mathrm{~mol} \mathrm{dm}^{-3}$ green line, $1.0 \times 10^{-5} \mathrm{~mol} \mathrm{dm}^{-3}$ orange line, $1.0 \times 10^{-4} \mathrm{~mol} \mathrm{dm}^{-3}$ red line) in $0.1 \mathrm{~mol} \mathrm{dm}^{-3}$ phosphate buffer ( $\mathrm{pH} 7.0$ ), sweep rate $50 \mathrm{mV}$ $s^{-1}$ (only the first sweep is recorded). Inset: The dependency of the value of the oxidative currents of CBZ at $0.90 \mathrm{~V}$ on the concentration in the range $1.0 \times 10^{-7}-1.0 \times 10^{-4} \mathrm{~mol} \mathrm{dm}^{-3}$.

formation of the current shoulder with the maximum value at $0.95 \mathrm{~V}$. The first gold oxide peak at $0.75 \mathrm{~V}$ completely diminished as shown in Fig. 2. Because it has tendency to undergo poisoning after the first sweep, gold electrode has been polished between successive additions of suitable aliquots of the working solution of CBZ in phosphate buffer solution to obtain good reproducible results, improved sensitivity and resolution of voltammetric peaks. Comparing to GCE, gold electrode does not require anodic pretreatment for its activation and its polishing and cleaning between the consecutive concentrations of analyte is quite simple and cheap procedure [13]. Both electrodes exhibit abilities for efficient, fast simple and cheap voltammetric determination of CBZ. The value of the oxidative currents of pure $C B Z$ at $0.90 \mathrm{~V}$ in $0.1 \mathrm{dm}^{-3}$ phosphate buffer at the scan rate of $50 \mathrm{mV} \mathrm{s}^{-1}$ is a linear function of the concentration in a range of $1 \times 10^{-7}-1 \times 10^{-4} \mathrm{~mol}$ $\mathrm{dm}^{-3}$. This linearity is presented by Eq. (1) and given in the left corner of Fig. 2:

$j\left(\mathrm{~mA} \mathrm{~cm}^{-2}\right)=0.0588+83.3 c\left(\mathrm{~mol} \mathrm{dm}^{-3}\right), R=0.998$

Thus, the proposed method, using cyclic voltammetry on gold electrode, enabled the detection of CBZ, even at the concentration of $1.0 \times 10^{-8} \mathrm{~mol} \mathrm{dm}^{-3}$, which is among the lowest that have been reported for this drug using voltammetric techniques so far $[1,18]$.

The voltammetric characterization of CBZ, as a content of tablets (Galepsin ${ }^{\circledR}$ ) in the concentration range from $1.0 \times 10^{-6}$ to $1.0 \times 10^{-4} \mathrm{~mol} \mathrm{dm}^{-3}$, is presented in Fig. 3. The cyclic voltammograms of Galepsin $^{\circledR}$ tablets shows the same shape and the current maximum at $1.10 \mathrm{~V}$, as it is observed for the standard. The negligible smaller anodic activity from 0.80 to $1.00 \mathrm{~V}$ may be attributed only to the presence of the excipients. The present excipients obviously do not affect the electrooxidation of CBZ and enable its quantitative determination as content of tablets (Galepsin ${ }^{\circledR}$ ).

The value of the oxidative currents of CBZ (in Galepsin $^{\circledR}$ ) at $0.90 \mathrm{~V}$ vs. SCE in $0.1 \mathrm{~mol} \mathrm{dm}^{-3}$ phosphate buffer solution at the scan rate of $50 \mathrm{mV} \mathrm{s}^{-1}$ is a linear function of the concentration in the range of $1.0 \times 10^{-6}$ $-1.0 \times 10^{-4} \mathrm{~mol} \mathrm{dm}^{-3}$. This linearity is presented by Eq. (2) and given in the left corner of Fig. 3 :

$$
j\left(\mathrm{~mA} \mathrm{~cm}{ }^{-2}\right)=0.0506+118 c\left(\mathrm{~mol} \mathrm{dm}^{-3}\right), R=0.995
$$

Serum albumin is the most abundant protein in blood plasma and is responsible for the binding and transportation of various drugs. BSA is an ideal model protein for serum albumin due to its availability, stab- 


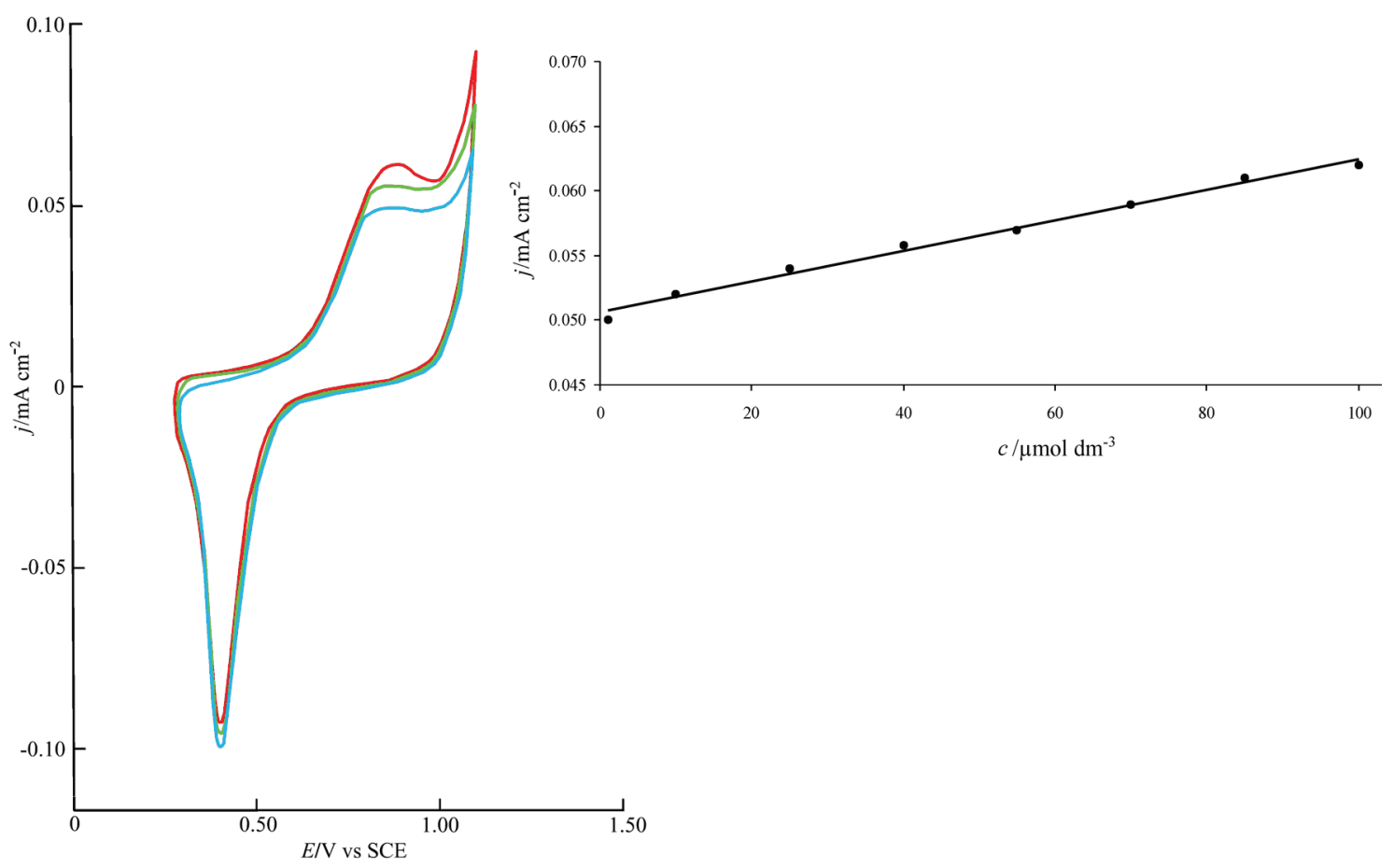

Figure 3. The cyclic voltammograms of carbamazepine (CBZ) as a content of tablets (Galepsin ${ }^{\circledR}$ ) in the concentration from $1.0 \times 10^{-6}$ to $1.0 \times 10^{-4} \mathrm{~mol} \mathrm{dm}^{-3}\left(1.0 \times 10^{-6} \mathrm{~mol} \mathrm{dm}^{-3}\right.$ blue line, $1.0 \times 10^{-5} \mathrm{~mol} \mathrm{dm}^{-3}$ green line, $\left.1.0 \times 10^{-4} \mathrm{~mol} \mathrm{dm}^{-3} \mathrm{red} \mathrm{line}\right)$ in $0.1 \mathrm{~mol} \mathrm{dm}^{-3}$ phosphate buffer ( $\mathrm{pH}$ 7.0), sweep rate $50 \mathrm{mV} \mathrm{s}^{-1}$ (only the first sweep is recorded). Inset: The dependency of the value of the oxidative currents of $C B Z$ at $0.90 \mathrm{~V}$ on the concentration in the range $1.0 \times 10^{-6}-1.0 \times 10^{-4} \mathrm{~mol} \mathrm{dm}^{-3}$.

ility and incomparable binding property [25]. The electrochemical behaviour of various proteins at gold electrode surfaces has been widely investigated in recent years (e.g., a gold electrode modified by gelatin [26], nafion-riboflavin [27], BSA [28]). To study the binding of $\mathrm{CBZ}$ to plasma proteins, its electrochemical behaviour on gold electrode modified with BSA, has been investigated, whereby a decrease of the oxidative peak currents as a result of the drug adsorption on the surface of the modified electrode has been expected. Figure 4 represents the cyclic voltammogram of gold electrode modified with BSA, as well as in the presence of the CBZ standard at the concentration of $1.0 \times 10^{-4} \mathrm{~mol} \mathrm{dm}^{-3}$ in $0.1 \mathrm{~mol} \mathrm{dm}^{-3}$ phosphate buffer solution. This concentration of the drug has been chosen, because its blood plasma levels may range from $2.1 \times 10^{-6}$ to $1.1 \times 10^{-4} \mathrm{~mol}$ $\mathrm{dm}^{-3}$ [29].

Gold modified by BSA exhibited almost two times lower currents in the whole region of the applied potential, which results from the strong adsorption of BSA on gold. It can be seen that the oxidative peak current has been decreased after adding the CBZ standard at the concentration of $1.0 \times 10^{-4} \mathrm{~mol} \mathrm{dm}^{-3}$ due to the binding of the drug to BSA. An ultraviolet and fluorescence spectroscopic study has indicated that the interaction between $\mathrm{CBZ}$ and $\mathrm{BSA}$ in Tris- $\mathrm{HCl}$ buffer solution ( $\mathrm{pH} 7.4$ ) is mainly driven by the hydrophobic force; the apparent binding constant and the binding site values at $27^{\circ} \mathrm{C}$ are $1.8 \times 10^{4}$ and 0.97 , respectively [30].

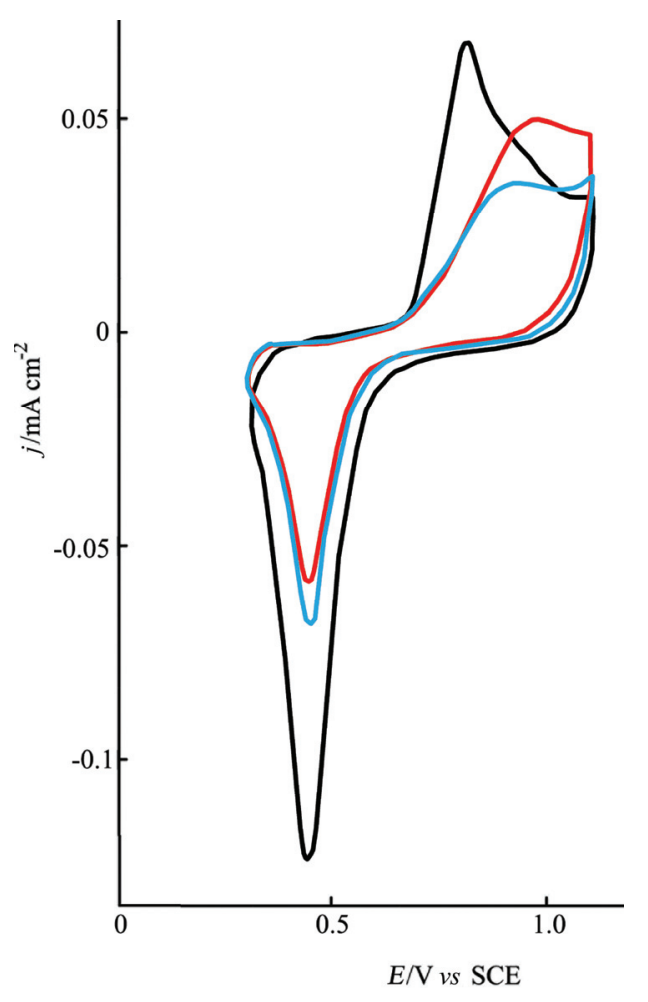

Figure 4. The cyclic voltammograms of bare gold electrode (black line), modified with bovine serum albumine (red line) and in the presence of the carbamazepine standard (blue line) at the concentration of $1.0 \times 10^{-4} \mathrm{~mol} \mathrm{dm}^{-3}$ in $0.1 \mathrm{~mol} \mathrm{dm}^{-3}$ phosphate buffer ( $\mathrm{pH} 7.0$ ), sweep rate $50 \mathrm{mV} \mathrm{s}^{-1}$ (only the first sweep is recorded). 


\section{CONCLUSION}

The proposed procedure enabled the detection of CBZ even at the concentration of $1.0 \times 10^{-8} \mathrm{~mol} \mathrm{dm}^{-3}$, which is among the lowest that have been reported for this drug using voltammetric techniques. Thus, the anodic behaviour of CBZ on gold electrode in $0.1 \mathrm{~mol}$ $\mathrm{dm}^{-3}$ phosphate buffer of $\mathrm{pH} 7.0$ has shown that the value of the oxidative currents at $0.90 \mathrm{~V} v \mathrm{~s}$. SCE is a linear function of the concentration in a range from $1.0 \times 10^{-7}$ to $1.0 \times 10^{-4} \mathrm{~mol} \mathrm{dm}^{-3}$. The $\mathrm{CBZ}$, as a content of tablet Galepsine ${ }^{\circledR}$, has also been quantitatively determined in a range from $1.0 \times 10^{-6}$ to $1.0 \times 10^{-4} \mathrm{~mol} \mathrm{dm}^{-3}$.

The electrooxidative behaviour of $\mathrm{CBZ}$ on gold electrode modified with $\mathrm{BSA}$ indicates a strong interaction between the drug and BSA, which is mainly driven by the hydrofobic force.

The simple, fast and cheap voltammetric procedure using gold electrode for the CBZ determination can be further developed as an additional method offering useful combinations with HPLC and with already investigated electrodes, such as glassy carbon electrode.

\section{Acknowledgement}

The authors are grateful to the Ministry of Education, Science and Technological Development of the Republic Serbia for financial support (Project 172013).

\section{REFERENCES}

[1] B. LeDuc, in: T.L. Lemke, D.A. Williams (Eds.), Foye's Principles of Medicinal Chemistry, $6^{\text {th }}$ ed., Lippincott Williams \& Wilkins, Philadelphia, 2008, pp. 531.

[2] C.C. Kuo, A common anticonvulsant binding site for phenytoin, carbamazepine, and lamotrigine in neuronal $\mathrm{Na}+$ channels, Mol. Pharmacol. 54 (1998) 712-721.

[3] C.C. Kuo, R.S. Chen, L. Lu, R.C. Chen, Carbamazepine inhibition of neuronal $\mathrm{Na}^{+}$currents: quantitative distinction from phenytoin and possible therapeutic implications, Mol. Pharmacol. 51 (1997) 1077-1083.

[4] G.K. McEvoy Ed., AHFS Drug Information 95, American Society of Health-System Pharmacists, Inc., Bethesda, 1995, pp. 1449.

[5] A. Dasgupta, C. McNeese, A. Wells, Interference of carbamazepine and carbamazepine 10,11-epoxide in the fluorescence polarization immunoassay for tricyclic antidepressants: Estimation of the true tricyclic antidepressant concentration in the presence of carbamazepine using a mathematical model, Am. J. Clin. Pathol. 121 (2004) 418-425.

[6] R.B. Miller, M. Vranderick, A validated HPLC method for the determination of carbamazepine and carbamazepine 10,11-epoxide in human plasma, J. Liq. Chromatogr. 16 (1993) 1249-1261.

[7] C.E. Leite, G.O. Petersen, A. Lunardelli, F.V. Thiesen, A high-performance liquid chromatography method for the determination of carbamazepine and carbamazepine-10,11-epoxide and its comparison with chemi- luminescent immunoassay, Clin. Chem. Lab. Med. 47 (2009) 458-463.

[8] U.K. Chhalotiya, K.K. Bhatt, D.A. Shah, S.L. Baldania, J.R. Patel, Stability-indicating liquid chromatographic method for quantification of new anti-epileptic drug lacosamide in bulk and pharmaceutical formulation, Chem. Ind. Chem. Eng. Q. 18 (2012) 35-42.

[9] W.R. Külpmann, A gas-chromatographic method for the determination of carbamazepine, phenobarbital, phenytoin and primidone in the same extract of serum, J. Clin. Chem. Clin. Biochem. 18 (1980) 227-232.

[10] U. Jürgens, T. May, K. Hillenkötter, B. Rambeck, Systematic comparison of three basic methods of sample pretreatment for high-performance liquid chromatographic analysis of antiepileptic drugs using gas chromatography as a reference method, Ther. Drug Monit. 6 (1984) 334$-343$.

[11] J. Hallbach, H. Vogel, W. G. Guder, Determination of lamotrigine, carbamazepine, and carbamazepine epoxide in human serum by gas chromatography mass spectrometry, Eur. J. Clin. Chem. Clin. Biochem. 35 (1997) 755-759.

[12] F.M. Lancas, M.A. Sozza, M.E.C. Queiroz, Simultaneous plasma lamotrigine analysis with carbamazepine, carbamazepine 10,11 epoxide, primidone, phenytoin, phenolbarbital, and PEMA by micellar electrokinetic capillary chromatography (MECC), J. Anal. Toxicol. 27 (2003) 304-308.

[13] S.S. Kalanur, J. Seetharamappa, Electrochemical oxidation of bioactive carbamazepine and its interaction with DNA, Anal. Lett. 43 (2010) 618-630.

[14] A. Veiga, A. Dordio, A. J. P. Carvalho, D. M. Teixeira, J. G. Teixeira, Ultra-sensitive voltammetric sensor for trace analysis of carbamazepine Anal. Chim. Acta 674 (2010) 182-189.

[15] S. Atkins, J. M. Sevilla, M. Blazquez, T. Pineda, J. Gonzalez-Rodriguez, Electrochemical behavior of carbamazepine in acetonitrile and dimethylformamide using glassy carbon electrodes and microelectrodes, Electroanal. 22 (2010) 2961-2966.

[16] S. Pruneanu, F. Pogacean, A.R. Biris, S. Ardelean, V. Canpean, G. Blanita, E. Dervishi, A.S. Biris, Novel graphene-gold nanoparticle modified electrodes for the high sensitivity electrochemical spectroscopy detection and analysis of carbamazepine, J. Phys. Chem., C 115 (2011) 23387-23394.

[17] W.Y. Lin, M.L. Pan, H.Y. Wang, Y.O. Su, P.W. Huang, Analysis of carbamazepine serum by differential pulse voltammetry (DPV) and comparison with fluorescence polarization immunoassay (FPIA): an animal study, Med. Chem. Res. 21 (2012) 4389-4394.

[18] S.S. Kalanur, J. Seetharamappa, S. Balakrishnan, Enhanced electrochemical response of carbamazepine at a nano-structured sensing film of fullerene-C60 and its analytical applications, Electrochim. Acta 56 (2011) 5295-5301.

[19] M.L. Avramov Ivić, S.D. Petrović, D.Ž. Mijin, P.M. Živković, I.M. Kosović, K.M. Drljević, M.B. Jovanović, Studies on electrochemical oxidation of azithromycin and 
Hemomycin at gold electrode in neutral electrolyte, Electrochim. Acta 51 (2006) 2407-2416.

[20] K.M. Drljević-Djurić, V.D. Jović, U.Č. Lačnjevac, M.L. Avramov Ivić, S.D. Petrović, D.Ž. Mijin, S.B. Djordjević, Voltammetric and differential pulse determination of roxithromycin, Electrochim. Acta 56 (2010) 47-52.

[21] M.L. Avramov Ivić, S.D. Petrović, P.M. Živković, D.Ž. Mijin, K.M. Drljević, A study of the catalytic role a gold electrode in the electrochemical activation of four macrolide antibiotics in sodium bicarbonate solution, Chem. Ind. Chem. Eng. Q. 16 (2010) 111-116.

[22] W.Y. Liu, K.J. Zhang, Electrochemical experimental investigation on behavior and mode of the interaction between DNA and (S)-2-(5-fluorouracil-1-acetyl) amido-1,4-succinic acid, Int. J. Electrochem. Sci. 6 (2011) 1066-1074.

[23] R.A. Gu, P.G. Cao, Y.H. Sun, Z.Q. Tian, Surface-enhanced Raman spectroscopy studies of platinum surfaces in acetonitrile solutions, J. Electroanal. Chem. 528 (2002) 121$-126$.

[24] M. Avramov-Ivić, S. Štrbac, V. Mitrović, The electrocatalytic properties of the oxides of noble metals in the electrooxidation of methanol and formic acid, Electrochim. Acta 46 (2001) 3175-3180.
[25] T. Peters, in: F. W. Putnam (Ed.), The Plasma Proteins, Elsevier Academic Press, San Diego, CA, 1975, pp. 133.

[26] K. de Wael, A. Verstraete, S. van Vlierberghe, W. Dejonghe, P. Dubruel, A. Adriaens, The electrochemistry of a gelatin modified gold electrode, Int. J. Electrochem. Sci. 6 (2011) 1810-1819.

[27] S. Rezaei-Zarchi, A.A. Saboury, J. Hong, P. Norouzi, A.B. Moghaddam, H. Ghourchian, M.R. Ganjali, A.A. Moosavi-Movahedi, A. Javed, A. Mohammadian, Electrochemical behavior of redox proteins immobilized on nafionriboflavin modified gold electrode, Bull. Korean Chem. Soc. 28 (2007) 2266-2270.

[28] Q. Xie, C. Xiang, Y. Yuan, Y. Zhang, L. Nie, S. Yao, A novel dual-impedance-analysis EQCM system-investigation of bovine serum albumin adsorption on gold and platinum electrode surfaces, J. Colloid Interface Sci. 262 (2003) 107-115.

[29] http://pharma.us.novartis.com/product/pi/pdf/tegretol. pdf

[30] C. Wang, Q.H. Wu, Z. Wang, J. Zhao, Study of the interaction of carbamazepine with bovine serum albumin by fluorescence quenching method, Anal. Sci. 22 (2006) 435-438.

\title{
IZVOD
}

\section{ELEKTROHEMIJSKO KARAKTERISANJE I ODREĐIVANJE KARBAMAZEPINA KAO FARMACEUTSKOG STANDARDA I SADRŽAJA TABLETE NA ELEKTRODI OD ZLATA}

\author{
Nemanja P. Trišović ${ }^{1}$, Bojan Đ. Božić ${ }^{1}$, Slobodan D. Petrović ${ }^{1}$, Svetlana J. Tadić ${ }^{2}$, Milka L. Avramov Ivić ${ }^{3}$ \\ ${ }^{1}$ Univerzitet u Beogradu, Tehnološko-metalurški fakultet, Karnegijeva 4, 11120 Beograd, Srbija \\ ${ }^{2}$ Galenika a.d., Batajnički drum bb, 11080 Beograd, Srbija \\ ${ }^{3}$ Univerzitet u Beogradu, IHTM, Institut za elektrohemiju, Njegoševa 12, 11000 Beograd, Srbija

\section{(Naučni rad)}

Anodno ponašanje jednog od najsigurnijih i najefikasnijih antikonvulzivnih lekova karbamazepina (CBZ) proučavano je po prvi put na elektrodi od zlata u 0.1 $\mathrm{mol} \mathrm{dm}^{-3}$ fosfatnom puferu $\mathrm{pH} 7.0$ pomoću ciklične voltametrije. Karbamazepin kao standard i kao sastojak komercijalnog oblika ( tablete) Galepsin ${ }^{\circledR}$ podleže anodnoj oksidaciji. Utvrđeno je da je vrednost struja oksidacije čistog CBZ-a na $0.90 \mathrm{~V}$ linearna funkcija koncentracija $u$ opsegu od $1.0 \times 10^{-7}$ do $1.0 \times 10^{-4} \mathrm{~mol} \mathrm{dm}^{-3}$. CBZ je detektovan i u koncentaraciji od $1.0 \times 10^{-8} \mathrm{~mol} \mathrm{dm}^{-3}$ koja je među najnižim koje su objavljene do sada za ovaj lek korišćenjem voltametrijskih tehnika. CBZ kao sadržaj tablete Galepsin ${ }^{\circledR}$ je kvantitativno određen, pri čemu je na $0.90 \mathrm{~V}$ takođe dobivena linearna zavisnost vrednosti struja oksidacije od ispitivanih koncentracija leka $\left(1.0 \times 10^{-6}-1.0 \times 10^{-4} \mathrm{~mol} \mathrm{dm}^{-3}\right)$. Pokazano je da prisutni ekscipijenti $\mathrm{u}$ tableti ne utiču na proces elektrooksidacije CBZ u fosfatnom puferu. Takođe je pokazano da modifikovanje elektrode od zlata albuminom goveđeg seruma (BSA) ima za posledicu smanjenje struja oksidativnog pika CBZ-a usled vezivanja leka za BSA. Kvantitativno određivanje CBZ i kao sadrzaja tablete Galepsin ${ }^{\circledR}$ na elektrodi od zlata cikličnom voltametrijom u fosfatnom puferu pH 7.0 je brza, jednostavna i efikasna metoda koja je korisna dopuna standardnoj metodi, tečnoj hromatografiji visokih performansi (HPLC).
Ključne reči: Karbamazepin • Voltametrijsko određivanje • Elektroda od zlata 